\title{
The Development Of Textbook In Growing The Character Of Students
}

\author{
Muhammad Yakob ${ }^{1}$, Molani Paulina Hasibuan ${ }^{2}$, \& Ratih Permana Sari ${ }^{2}$ \\ \{myakob@unsam.ac.id, molanipaulinahsb@unsam.ac.id\} \\ ${ }^{1}$ Physic Education Study Program, Universitas Samudra,Langsa, Indonesia \\ ${ }^{2}$ Chemistry Education Study Program,Universitas Samudra, Langsa, Indonesia
}

\begin{abstract}
This study aims to measure the effectiveness of chemistry textbooks in High School Class XI Semester 1 generated in this study in developing the character of students so that in accordance with the objectives of the 2013 curriculum. The sample of this research are chemistry teachers in senior high school at Medan City, North Sumatra Province. The sample was taken purposively. The approach used to achieve the objectives that have been formulated is qualitative descriptive research. Data in the form of conformity assessment of the contents of the book with the character to be developed. Data obtained from the questionnaire given to the respondents are high school chemistry teachers in Medan City. Prior to giving treatment to the sample, a prerequisite test of data normality was done by SPSS 20 Kolmogorof-Smirnov test at significance level $\alpha=0,05$. The results showed that the chemistry textbook developed in this research was effective in developing the character of responsibility, creativity, and communicative. This can be seen from the results of book assessments that indicate that the average assessment results fall into the "high" category.
\end{abstract}

Keywords: Textbook, Character, Curriculum

\section{Introduction}

Teaching materials or textbooks are the dominant instructional medium of their role in the classroom and the central part of the education system [1]. This is because the textbook is an important tool for delivering curriculum materials. The need for textbooks occupies the most important priority scale. This is because the textbook not only serves as a teaching resource that provides learning materials, but even functions as a syllabus. The textbooks provide instructional guidance to teachers, allowing teachers to teach without having to look at the syllabus. Thus, the quality of classroom teaching is not independent of the type of textbook used

In the 2013 curriculum, there is a formula of Core Competencies and Basic Competencies that include character education must be integrated in the learning process. Therefore, teaching materials should be equipped with teaching materials that support the achievement of core competencies and basic competencies as formulated in the curriculum 2013. Curriculum 2013 focused on the formation of competence and character of learners, in the form of guides 
knowledge, skills, and attitudes that demonstrated learners as a form of understanding of concepts that he learned conceptually[2]-[6]. The development of teaching materials should be directed to the fulfillment of curriculum standards as an effort in achieving educational objectives. Development of teaching materials produced should be able to support the development of student character in the learning process so that in accordance with the 2013 curriculum. Therefore, the resulting teaching materials must be specially designed to develop the character of the students.

One of the top concerns about science teaching in secondary schools and universities is the new design of textbooks with systems and special exercises for students' self-employment so that they discover the ability to learn by themselves[7]. Science textbooks have long been a key issue in science learning. Many reports indicate that textbooks play a dominant role in the teaching of science and have a profound effect on the choice of concepts as best as they are taught. In addition, if analogy is provided in textbooks, teachers can use teaching models using analogies to improve student learning[4], [8]-[12]

A well-considered element in a textbook is effective learning in the sense that the content of the book is developed to achieve the competencies set out in the curriculum. Therefore, the research was conducted with the aim to measure the effectiveness of chemistry textbook in SMA / MA Class XI Semester 1 which was produced in this research in developing the character of the students so that in accordance with the objectives of curriculum 2013. The measured character is responsibility, creativity, and communicative.

\section{METHOD}

This research was conducted at High School (SMA) and Madrasah Aliyah (MA) in Medan City, North Sumatera. The population of this research is the teacher of chemistry study in Medan City of the academic year 2013/2014. The sample was taken by purposive sampling technique based on the consideration of the researcher. The type of approach used in this study to achieve the objectives that have been formulated is qualitative descriptive research.

The steps taken are: preparing questionnaires/ questionnaires about book assessments, then providing questionnaire questionnaires to books on chemistry teachers. The type of data obtained at this stage is the qualification data in the form of responses from the teacher. Then the assessment (response) obtained is collected and tabulated and calculated average assessment of the feasibility of the content, language feasibility, and feasibility of presentation in accordance with the objectives of the 2013 curriculum.

This study was conducted with the aim to measure the effectiveness of chemistry textbooks in SMA / MA Class XI Semester 1 which was produced in this research in developing the character of the students so that in accordance with the purpose of curriculum 2013.For that conducted data collection to compare the book being used in schools SMA / MA, which is a book based on curriculum KTSP with books developed in this study, the book based on the curriculum 2013. The data obtained in the form of questionnaires respondents for the assessment of the effectiveness of the book.

Data in the form of conformity assessment of the contents of the book presentation with the development of creativity, curiosity, environmental care, love the homeland, and love to read. Data obtained from the questionnaire given to the respondents are high school chemistry teachers / MA in Medan City. Each indicator in the questionnaire is given a score of $1-4$, then 
the score is summed and given the value, then the value obtained is seen normality with Kolmogorof-Smirnov test at significance level $\alpha=0.05$.

Hypothesis test data obtained can be done after the prerequisite test first, the test data normality. Normality test data is done on the data of research results that is the average assessment of the results of character assessment contained in the book by using SPSS 20 Kolmogorof-Smirnov test with a significant level $\alpha=0.05$.

\section{RESULT AND DISCUSSION}

The data obtained to illustrate the results of research that is the average assessment of the results of character assessment contained in the book. The sample in the research for the quality assessment of books conducted on high school teachers / MA in Medan.

Table 1. Description of Data Average Score The result of character assessment contained in the book

\begin{tabular}{llcc}
\hline \multicolumn{1}{c}{ Rating } & Description data & Mean & Deviation value \\
\hline & Creativity & 79,91 & 11,39 \\
& Curiosity & 81,27 & 9,32 \\
& & & \\
$\begin{array}{l}\text { Characters in } \\
\text { Books }\end{array}$ & Like to read & 75,52 & 8,23 \\
& Love the & 76,52 & 13,54 \\
& homeland & & \\
& Enviromental care & 71,09 & 16,26 \\
& & & \\
\hline
\end{tabular}

Assessment of the growth of character, namely creativity, curiosity, love to read, love the homeland, and care about the environment also shows a good average. For the average creativity character of $79.91 \pm 11.39$, it is categorized as "high". The average curiosity character of $81.29 \pm 9.32$ is categorized as "very high". The average reading character of 75.52 \pm 8.23 is categorized as "high". The character of love of the homeland averages $76.52 \pm 13.54$ is categorized as high. And finally, the average environmental care character of $71.09 \pm 16.26$ is categorized as "high".

Normality test data is done on the data of research results that is the average assessment of the results of character assessment contained in the book by using SPSS 20 KolmogorofSmirnov test with a significant level $\alpha=0.05$ and obtained data as in Table 2 . 
So, from the results of the analysis, it can be concluded that the chemistry textbook developed in this research is effective in developing the character of creativity, curiosity, reading, love of the homeland, and caring environment because the average category is "high".

Table 2. Normality Test Results Data Quality Rating Book

\begin{tabular}{lcccc}
\hline Data & $\begin{array}{c}\text { Kolmogorof- } \\
\text { Smirnov }\end{array}$ & $\boldsymbol{\alpha}$ & Information \\
\hline Responsible & 1,895 & 0,05 & $\begin{array}{c}\text { Data is normally } \\
\text { distributed }\end{array}$ \\
Creativity & 1,876 & 0,05 & $\begin{array}{c}\text { Data is normally } \\
\text { distributed }\end{array}$ \\
Comunicative & 1,677 & 0,05 & $\begin{array}{c}\text { Data is normally } \\
\text { distributed }\end{array}$
\end{tabular}

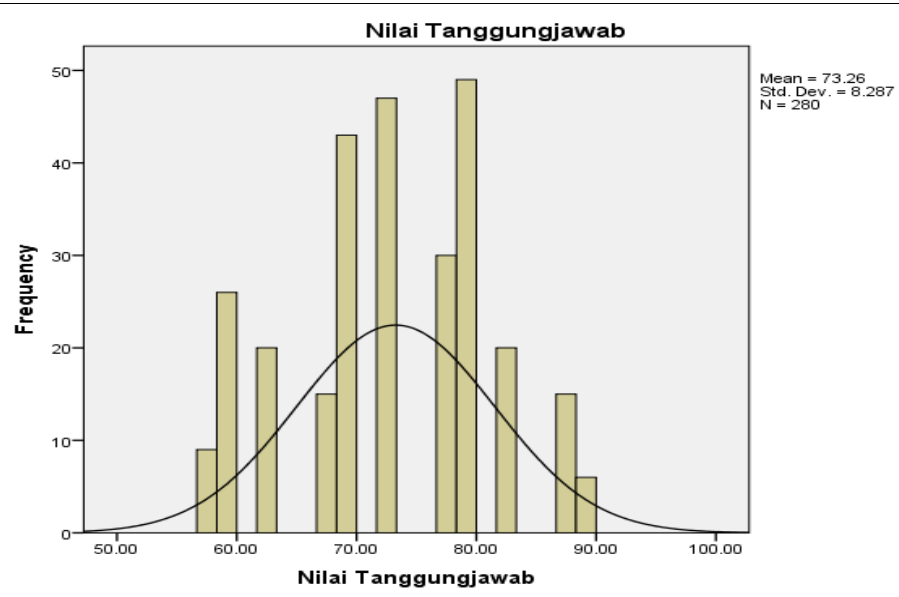

Fig. 1 Characteristic normality test result responsibility

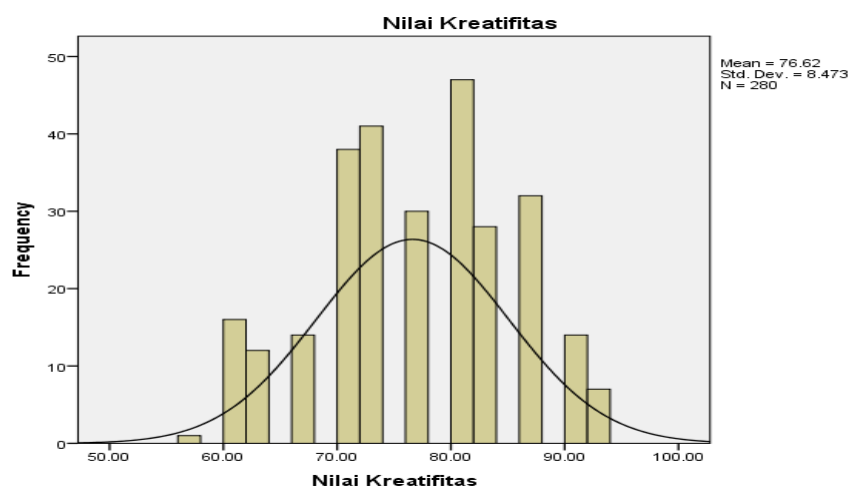

Fig. 2 Characteristic normality test result creativity 


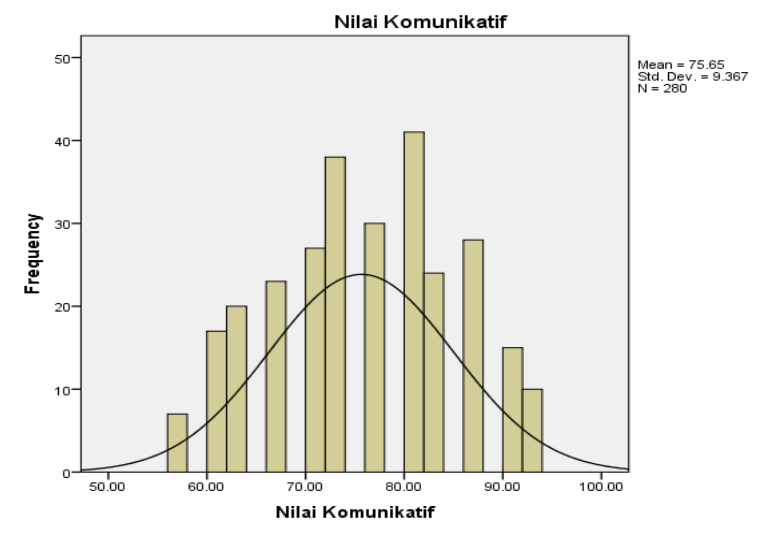

Fig. 3 Characteristic normality test result communicative

\section{CONCLUSION}

Chemical textbooks developed in this research are effective in developing the character of creativity, curiosity, love reading, love homeland, and care for the environment. This can be seen from the results of book assessments that indicate that the average assessment results go into the "high" category. So it can be concluded that the needs analysis here concluded the book Curriculum 2013 needs to be developed.

\section{REFERENCE}

[1] I. Nursamsudin, S. Nuriman , Indrawati, and J. Prihatin, "The Development of Chemical Impacts Based on Drawing Processes on Electrolite and Non-Elektrolite Materials for Learning in SMA," Int. J. Soc. Sci. Humanit. Invent., vol. 4, no. 11, pp. 4098-4105, 2017.

[2] A. Sudrajat, "Mengapa Pendidikan Karakter?," J. Pendidik. Karakter, vol. 1, no. 1, pp. 47-58, 2011.

[3] C. Z. Harun, "Manajemen Pendidikan Karakter," J. Pendidik. Karakter, no. 3, pp. 302-308, 2015.

[4] Y. K. Adi and U. Kuningan, “Analisis Muatan Pendidikan Karakter,” pp. 23-36, 2013.

[5] Murni Eva Marlina, "Kurikulum 2013 Yang Berkarakter,” J. JUPIIS 2085-482X, vol. Vol 5, no. No 2, pp. 27-38, 2013.

[6] D. Setiawan, "Peran pendidikan karakter dalam mengembangkan kecerdasan moral," J. Pendidik. Karakter, vol. 3, no. 1, pp. 53-63, 2013.

[7] N. S. Dwi Astuti D. K, Ani R, "Pengembangan Buku Suplemen Ipa Terpadu Dengan Tema Pendengaran Kelas Viii," Unnes Sci. Educ. J., vol. 3, no. 2, pp. 462-467, 2014. 
[8] P. Perangkat, P. Ipa, and T. Di, "Journal of Innovative Science Education," J. Innov. Sci. Educ., vol. 1, no. 1, pp. 1-9, 2012.

[9] N. Unrau and J. Schlackman, "The Journal of Educational Research," J. Educ. Res., vol. 2, no. May 2012, pp. 37-41, 2010.

[10] P. Dan, K. Smp, and K. Viii, “nilai karakter, buku teks,” no. 1, pp. 1-9.

[11] M. P. Li and B. H. Lam, "Cooperative learning," Act. Classroom, Hong Kong Institude Educ., pp. 1-13, 2013.

[12] N. I. Ward and R. L. Laslett, "International Cooperative Education Student Exchange Program: Lessons from the Chemistry Experience," 2004. 